This item was submitted to Loughborough's Research Repository by the author.

Items in Figshare are protected by copyright, with all rights reserved, unless otherwise indicated.

\title{
The impact of delayed maternity on foetal growth in Spain: An assessment
}

\section{by population attributable fraction}

PLEASE CITE THE PUBLISHED VERSION

https://doi.org/10.1016/j.wombi.2017.09.004

\section{PUBLISHER}

Elsevier () Australian College of Midwives

\section{VERSION}

AM (Accepted Manuscript)

\section{PUBLISHER STATEMENT}

This work is made available according to the conditions of the Creative Commons Attribution-NonCommercialNoDerivatives 4.0 International (CC BY-NC-ND 4.0) licence. Full details of this licence are available at: https://creativecommons.org/licenses/by-nc-nd/4.0/

\section{LICENCE}

CC BY-NC-ND 4.0

\section{REPOSITORY RECORD}

Varea, Carlos, Jose Manuel Teran, Cristina Bernis, and Barry Bogin. 2019. "The Impact of Delayed Maternity on Foetal Growth in Spain: An Assessment by Population Attributable Fraction”. figshare. https://hdl.handle.net/2134/26754. 
The impact of delayed maternity on foetal growth in Spain: An assessment by population attributable fraction

Carlos VAREA ${ }^{\mathrm{a},} \mathrm{PhD}$, José Manuel TERÁN ${ }^{\mathrm{a}}$, MSc, Cristina BERNIS ${ }^{\mathrm{a}}$, PhD, Barry BOGIN $^{\mathrm{b}}, \mathrm{PhD}$

a Department of Biology, Faculty of Sciences, Madrid Autonomous University, Madrid, Spain.

${ }^{\mathrm{b}}$ School of Sport, Exercise and Health Sciences, Loughborough University, Loughborough, Leicestershire, UK.

\section{Corresponding author}

Carlos Varea

Department of Biology, Faculty of Sciences, Madrid Autonomous University, c/Darwin, 2, 28049 Madrid, Spain.

Phone: +91.497.81.49. Fax: +91.497.83.44.

E-mail: carlos.varea@uam.es 


\section{Abstract}

Background. Delayed childbearing is considered a risk factor for maternal-foetal health. As in other higher-income countries, in Spain age at maternity has steadily increased during the last two decades. Aim. To quantify the impact of the delay in the age at maternity on small for gestational age (SGA) categories of $<3^{\text {rd }}, 3^{\text {rd }}-5^{\text {th }}$ and $5^{\text {th }}-10^{\text {th }}$ percentiles. Methods. $2,672,350$ singleton live births born to Spanish mothers in 2007-2015 were analysed. Adjusted relative risk was calculated by Poisson regressions to estimate the adjusted partial population attributable fractions $\left(\mathrm{PAF}_{\mathrm{p}}\right)$ for primipara and multipara mothers aged $35-39$ and $\geq 40$ years for each category of SGA considering the interaction between age at maternity and parity. Findings. Primipara 35-39 years old mothers have the highest $\mathrm{PAF}_{\mathrm{p}}$ in the three categories of SGA, with the maximum value for SGA $<3^{\text {rd }}$ percentile $(2.57 \%$, 95\% CI $2.25,2.88)$. PAF $_{p}$ for both primipara and multipara $\geq 40$ years old mothers were less than $1 \%$. $\mathrm{PAF}_{\mathrm{p}}$ for the three categories of SGA increased significantly in 2007-2015 among primipara mature mothers, more clearly among those aged 35-39 years. The contribution of multipara mothers of both age groups did not increase significantly during the period. Conclusion. Delayed maternity is a significant adjusted risk factor for SGA, contributing to the increase of its prevalence. However, results also suggest a limited clinical impact of delayed maternity on foetal growth. Positive changes in maternal profile associated with the shift in maternal age might contribute to explain the discreet impact of mature mothers on negative birth outcome in Spain.

\section{Key words}

Age at maternity, Parity, Maternal profile, Small for gestational age, Partial population attributable fraction. 


\title{
Introduction
}

\author{
Statement of Significance \\ Problem \\ Delayed childbearing is a trend across higher-income countries, being increasingly considered a \\ major public health concern as an independent risk factor for maternal-foetal health, especially \\ small-for-gestational age (SGA) newborns.
}

\section{What is already known}

Older age at childbearing is an obstetric, labour, and birth outcome risk factor, becoming more evident with increasing age over 40 years old. Some studies, however, find that its impact may be significantly reduced or eliminated after adjustment for potential confounders.

\section{What this paper adds}

Delayed maternity associated with primiparity is a significant adjusted risk factor for SGA, contributing to the increase of its prevalence. However, results suggest a limited clinical impact, perhaps as a consequence of the high socioeconomic status profile of older mothers.

The past decades have seen a remarkable trend in higher-income countries towards delaying childbirth to later reproductive years, a tendency driven by the free access to highly effective contraception, expanding opportunities for higher education and professional employment among women, and the subsequent option of assisted reproductive techniques (ART). Mature mothers (usually considered as women aged 35 years or older) may be psychologically and socially better prepared for childbearing, when compared to younger mothers, due to greater education, higher-income, and better prenatal care. Due to biological limits on fertility, mature mothers are more heavily involved in their "valuable pregnancies". ${ }^{1}$ However, the trend to 
delayed childbearing is being increasingly regarded as a major public health concern in higherincome countries, considering that it is an independent risk factor for maternal health and birth outcome. It has been suggested that delayed childbearing may be reversing the general improvement achieved during the previous decades in the health of mothers and neonates. ${ }^{2}$ Moreover, the growing predominance of primipara mothers with an ever-increasing age at first maternity, and their growing rates of multiple pregnancies (twins, triplets) as a result of the rise in ART, have been proposed as the main explanations for the increasing rates of low birthweight (LBW) and preterm births described in almost all higher-income countries over the past two decades. $^{3}$

Some biological mechanisms have been proposed to explain the potential negative effect of delayed maternity on maternal and foetal health and type of delivery. Uteroplacental perfusion decreases as women grow older independently of parity, affecting foetal growth and even determining a higher risk of perinatal mortality. ${ }^{4}$ In a growing population of mature primipara mothers, primiparity contributes negatively to birth outcome mainly due to a lesser vascular uteroplacental capacity. ${ }^{5}$ Additionally, the life course increasing prevalence of chronic medical diseases (diabetes and hypertension) and obesity among mature mothers contributes to poorer birth outcome and increased maternal health problems (pregnancy-induced hypertension, preeclampsia, and diabetes mellitus) compared with healthy younger women. ${ }^{6}$ Finally, delayed childbirth has been associated with rising rates of intrapartum complications and, consequently, of Caesarean section (CS) and operative vaginal deliveries as a consequence of impaired myometrial function. ${ }^{7}$

The recent reviews by Carolan et al. ${ }^{8,9}$ confirm that delayed maternity is significantly associated with an increased prevalence and risk of obstetric complications (placenta praevia and placental abruption), adverse labour (breech presentation, and operative vaginal or CS delivery), and negative birth outcome (stillbirths, preterm birth, and newborns with LBW or small for gestational age), although these associations are significantly reduced or disappeared after adjustment for potential confounders (parity, maternal health profile, and socioeconomic and 
lifestyle factors), and are more evident with increasing age from $\geq 40$ years old. Subsequent analyses in higher-income countries seem to confirm that delayed age at maternity is an independent obstetric, labour, and birth outcome risk factor, ${ }^{10,11}$ although methodological disparities—specifically on the age groups compared and selection of confounders-make it difficult to draw strong conclusions.

Spain is currently one of the European countries with the highest mean age at first maternity. ${ }^{12}$ Between 1996 and 2015, age at first maternity among Spanish national mothers increased from 29.23 to 32.21 years old, and mean age at maternity (all parities considered) increased from 30.03 to 33.30 years old (compiled by the authors from the Spanish Birth Statistical Bulletin), a trend strengthened during the current economic crisis beginning in $2007 .{ }^{13}$ Simultaneously, throughout the decade prior to the economic crisis, Spain registered the greatest increase in LBW among the European countries in spite of the reduction in the prevalence of preterm births. ${ }^{3}$ The aim of this study is to quantify the possible impact of delaying maternity on foetal growth (small for gestational age —SGA—) in Spain during the period 2007-2015 by the assessment of adjusted partial population attributable fraction $\left(\mathrm{PAF}_{\mathrm{p}}\right)$ for primipara and multipara mothers with advanced (35-39 years old) and high ( $\geq 40$ years old) age at maternity considering previous evidences on the interaction between age at maternity and parity on birth outcome. $^{11}$

\section{Methods}

Data analysed came from the Spanish birth certificate (Spanish Birth Statistical Bulletin, Boletín Estadístico de Partos), the compulsory civil registration of all births. Since 1996 the Spanish birth certificate includes the nationality of parents, and in the revised version of 2007 includes new variables of interest, including marital status, level of education of both parents, and type of delivery. Validation studies have concluded that data provided by the Spanish birth certificate are highly reliable when compared with hospital birth statistics. ${ }^{14}$ The three main groups of immigrant mothers in Spain (Latin-American, North African, and Eastern European women) 
have very different lifestyles, cultural practices, nutritional behaviour and genetic heritage, showing different trends in reproductive profile and birth outcome compared with Spanish mothers. ${ }^{15}$ As in other high income countries, ${ }^{3}$ delayed maternity is associated in Spain with an increased access to ART and the consequent increase in multiple pregnancies, so that $70 \%$ of twin pregnancies are estimated to be due to fertility treatment. ${ }^{16}$ Due to these reasons, analysis was restricted to Spanish women that delivered singleton live births (final sample $n=2,672,350$, $64.9 \%$ of all births registered in the analysed period: Figure 1).

SGA $<3^{\text {rd }}, 3^{\text {rd }}-5^{\text {th }}$ and $5^{\text {th }}-10^{\text {th }}$ percentiles were considered the dependent variables. Values of the three SGA categories have been established according to national birthweight charts by parity and type of delivery for the 2010-2014 period. ${ }^{17}$ Age at maternity was considered the independent variable and categorised in six age groups: <20 years old, 20-24 years old, 25-29 years old, 30-34 years old, 35-39 years old, and $\geq 40$ years old. Potential confounding variables included in the analysis were maternal education (primary education, secondary education, or university education), maternal occupation (professionals, administrative employees, service sector workers, primary sector workers, qualified workers, unskilled workers, students or housewives), marital status (married, with stable partner or with non-stable partner), residence of the mother (rural or urban residence), parity (primipara or multipara mothers), sex of the newborn, type of delivery (vaginal or CS delivery), and year of birth. Following descriptive analysis, adjusted $\mathrm{PAF}_{\mathrm{p}}$ by parity and maternal age group on the three categories of SGA were calculated.

Firstly, interactions between pairs of potential confounders on birth outcome were checked by bivariate Poisson regressions. Interaction between age at maternity and parity on the three categories of SGA was confirmed. No other interactions between potential confounders on birth outcome were detected.

Secondly, to avoid unnecessary adjustment when performing multivariable analysis, bivariate Poisson regressions on each category of SGA have been carried out between age at maternity and the aforementioned maternal-foetal variables in order to identify the confounders of the effect of age at maternity on birth outcomes. Because the conventional change-in-estimate (CIE) 
criterion of $10 \%$ between unadjusted and adjusted relative risk (RR) has been questioned, ${ }^{18}$ models established by this criterion were compared with those based on the z-score test, considering significant a change between unadjusted and adjusted regression coefficients [Ln(RR)] with a $p$-value $<0.05$. Goodness-of-fit of adjusted models was checked by the likelihood ratio test and accuracy was checked by analysing Area Under ROC Curve (AUC). Both for primipara and for multipara mothers CIE criterion based on $p$-value $<0.05$ yield models with the highest Log-Likelihood and accuracy. Maternal occupation, maternal education, marital status, gestational age, type of birth, parity and the interaction term between age at maternity and parity were identified as confounders of age at maternity on the three categories of SGA and included in the model.

Finally, adjusted $\mathrm{PAF}_{\mathrm{p}}$ were calculated. Unadjusted and adjusted relative risks (RR) of maternal age, parity and the interaction between both variables on the different categories of SGA were calculated (Supporting Information Table S1) considering the maternal groups with the lowest prevalence of the three categories of SGA (30-34 years old mothers, multipara, and 30-34 years old multipara mothers, respectively) as the reference categories. Adjusted partial PAF ( $\left.\mathrm{PAF}_{\mathrm{p}}\right)$ and their confidence intervals (CI) were then calculated according to Rothman et al. (2008) ${ }^{18}$ in order to evaluate the contribution of age at maternity, parity and their interaction to the prevalence of the three categories of SGA in the Spanish population during the period 20072015. Adjusted $\mathrm{PAF}_{\mathrm{p}}$ by year between 2007 and 2015 were also calculated to evaluate the temporal trends in the contribution of mothers aged 35-39 and $\geq 40$ years on the prevalence of SGA categories. Considering 2007 as the year of reference, a temporal change in adjusted $\mathrm{PAF}_{\mathrm{p}}$ was considered significant when CI did not overlap.

\section{Results}

Temporal trends in maternal-foetal variables for the years 2007, 2010 and 2015 are shown in

Table 1. Spanish mothers that delivered singleton births have become predominantly older women (44.1\% over 35 years old in 2015) and highly qualified professionals (54.9\% of women 
professional or administrative employees in 2015), with a substantial reduction of the contribution of housewives (from $21.6 \%$ in 2007 to $15.3 \%$ in 2015). Associated with these trends in age at maternity and occupation, the percentage of mothers with university education increased from 34.2\% to $41.4 \%$ between 2007 and 2015. Spanish mothers were predominantly urban dwellers and married or with a stable partner, although the percentage of women with non-stable partnerships increased significantly from $7.6 \%$ to $17.9 \%$ in the analysed period. Although still predominant, the rate of primiparity has been reduced from $59.1 \%$ to $53.6 \%$, while CS deliveries remained over 25\%. The prevalence of preterm births decreased significantly from $6.1 \%$ to $5.4 \%$. In contrast, the overall prevalence of SGA $\left(<10^{\text {th }}\right)$ increased significantly during the worst year of the economic crisis, 2010 (10.3\%).

The association between age at maternity and maternal profile and birth outcome is shown in Table 2. Both quality of employment and education level increased significantly with age at maternity, in such a way that more than half of the mothers over 35 years old were professionals or administrative employees, and college educated, while women under 24 years old were predominantly housewives and with low educational levels. Likewise, marital stability increased with age at maternity. As expected, primiparity reduced with age at maternity (at a minimum of 37.9\%, in mothers over 40 years old), while the rate of CS delivery increased from $14.1 \%$ in mothers $<20$ years old to $33.8 \%$ among those over 39 years old. The prevalence of preterm births and SGA $<10^{\text {th }}$ percentile newborns were higher among younger mothers $(9.1 \%$, and $11.7 \%$, respectively), decreasing with maternal age and increasing again slightly in 35-39 years old women (5.7, and 9.9\%, respectively), and more sharply among $\geq 40$ years old women (7.1\%, and $10.6 \%$, respectively).

Table 3 shows the adjusted PAF $_{\mathrm{p}}$ for the three categories of SGA by age at maternity, parity and their interaction. The highest adjusted $\mathrm{PAF}_{\mathrm{p}}$ for age at maternity was found among SGA $<3^{\text {rd }}$ percentile $(1.90 \%, 95 \%$ CI $1.15,2.60)$, and for parity among SGA $3{ }^{\text {rd }}-5^{\text {th }}$ percentile $(4.29 \%, 95 \%$ CI 3.16, 5.40). Considering the interaction between age at maternity and parity, total adjusted $\mathrm{PAF}_{\mathrm{p}}$ for $\mathrm{SGA}<3^{\text {rd }}$ percentile increased to $7.22 \%$ (95\% CI 6.41, 8.03). Compared with the category of reference (multipara 30-34 years old mothers), primipara 35-39 years old mothers 
showed the highest contributions in the three categories of SGA, with the maximum value to SGA $<3^{\text {rd }}$ percentile $(2.57 \%, 95 \%$ CI $2.25,2.88)$. The maternal group with the second highest $\mathrm{PAF}_{\mathrm{p}}$ was 30-34 years old primipara women, with the highest contribution to SGA $<3^{\text {rd }}$ percentile $\left(1.99 \%\right.$, 95\% CI 1.50, 2.47). In contrast, the $\mathrm{PAF}_{\mathrm{p}}$ for both primipara and multipara $\geq 40$ years old mothers were $<1 \%$ regarding the three categories of SGA.

Figures 2.a-d. show the temporal trend in the adjusted $\mathrm{PAF}_{\mathrm{p}}$ for SGA categories considering the interaction between age at maternity and parity in both groups of mature mothers. During the analysed period, adjusted $\mathrm{PAF}_{\mathrm{p}}$ for the three categories of SGA increased significantly among primipara 35-39 years old mothers (Figure 2.a, and Supporting Information Table S2), with a maximum contribution in 2015 to SGA $<3^{\text {rd }}$ percentile of $4.23 \%$ (95\% CI 3.08, 5.37). Furthermore, the contribution of primipara $\geq 40$ years old mothers to the prevalence of the three categories of SGA increased also significantly, although adjusted $\mathrm{PAF}_{\mathrm{p}}$ were substantial lower and the temporal trend is less clear (Figure 2.c, and Supporting Information Table S2). In contrast, $\mathrm{PAF}_{\mathrm{p}}$ for multipara mothers, both 35-39 years old (Figure 2.b, and Supporting Information Table S2) and $\geq 40$ years old women (Figure 2.d, and Supporting Information Table S2) did not show a significant increase for any category of SGA.

\section{Discussion}

Spain is one of the higher-income countries with a more recent and sharper trend in postponing childbearing. ${ }^{12}$ This study examined the impact of delayed childbearing on birth outcome in the country during the period of economic crisis (2007-2015), calculating adjusted PAF $F_{p}$ for SGA considering the interaction between age at maternity and parity. Results confirm that the contribution to national fertility of mothers of advanced (35-39 years old) and high ( $\geq 40$ years old) age at maternity increased during the analysed period, up to $44.1 \%$ in 2015 , an increase which was far beyond previous estimations for European countries ( 25\% by 2015). ${ }^{19}$ Between 2007 and 2015, the category of 35-39 years old mothers increased by one third, and that of $\geq 40$ years old mothers almost doubled. Delayed maternity was clearly associated with a higher 
socioeconomic status and marital stability, increased obstetric intervention (higher rate of CS deliveries), and a slightly higher prevalence of SGA among mature mothers-although lower than shown by mothers under 25 years old.

Results confirm that delayed maternity is a significant adjusted risk factor for foetal growth that is contributing to the increase of the prevalence of SGA newborns in Spain. Although younger mothers showed the highest prevalence of the three categories of SGA considered, the adjusted $\mathrm{PAF}_{\mathrm{p}}$ for both primipara and multipara mothers $\geq 35$ years old were higher, a consequence of their increasing demographic predominance among Spanish mothers and their higher adjusted RR. Results also confirm the need to consider the interaction between parity and age at maternity when assessing the impact of a delayed childbearing on birth outcome. Thus, primipara 35-39 years old mothers had the highest adjusted $\mathrm{PAF}_{\mathrm{p}}$ for the three categories of SGA, showing the most clear and sustained upward trend in the prevalence of SGA categories, especially for SGA $<3^{\text {rd }}$ percentile. The contributions to the prevalence of SGA categories by primipara $\geq 40$ years old mothers were more discrete, and there were no significant temporal increase from multipara mothers of both categories of mature mothers.

More than half of the Spanish mothers were primipara. Although primiparity reduced with age at maternity, as a consequence of the sustained trend to delay childbearing in the country, an ever-growing proportion of primipara mothers are also mature mothers. Between 2007 and 2015, the percentage of primipara mothers aged 35 years or older rose from $21.1 \%(n=38,521)$ to $34.2 \%(n=51,130)$ — an increase of $62.1 \%$ - while decreased among mothers of younger age. However, despite the steady, ever-growing contribution of primipara mature women to childbearing in Spain, results also suggest a limited clinical impact of delayed childbearing on birth outcome, as other studies have highlighted. ${ }^{20,21}$ Coinciding with previous studies, ${ }^{11,22}$ the contribution to the prevalence of SGA by primipara mature mothers was discreet, well below those $\mathrm{PAF}_{\mathrm{p}}$ obtained for the effect of harmful behaviours, ${ }^{23}$ poor maternal weight gain, ${ }^{24}$ or the exposure to air pollution ${ }^{25}$ during pregnancy. 
Positive changes in maternal profile associated with the shift in maternal age might contribute to explain this discreet impact of mature mothers on negative birth outcome in Spain. Delayed maternity is clearly associated with an increasing contribution of educated and wealthy women, a profile associated with greater stability and resources, lesser pregnancy anxiety, and better maternal care, ${ }^{26}$ and, finally, with better perinatal indicators. ${ }^{27} \mathrm{~A}$ favourable socioeconomic maternal profile reduces significantly, or cancels, the adverse effects of advanced maternal age on pregnancy and birth outcomes. ${ }^{9,10}$ This socioeconomic bias in maternal profile-strongly associated with the tendency to postpone childbearing-is deepening in Spain as a consequence of the economic crisis ${ }^{13}$ and might explain the temporal trends of $\mathrm{PAF}_{\mathrm{p}}$ described. Moreover, overall prevalence of SGA (and those of SGA $<3^{\text {rd }}$ ) percentile rise during the worst years of the economic crisis with a further reduction, perhaps an indication that this increase was due to the impact of the economic crisis on foetal growth through increased maternal stress, ${ }^{13}$ more than to the effect of delayed maternity, an hypothesis that requires a more extended time series analysis to be confirmed.

Results might challenge the consideration that the growing number of older primipara mothers represents as a specific obstetric risk group and, consequently, subjected to unnecessary or excessive obstetric interventionism. ${ }^{28}$ Our published analyses of data from one of the main maternity hospitals in Spain support the consideration that increasing obstetric interventions mainly on mature primipara mothers might be contributing to the reduction in birthweight though changes in the distribution of gestational age among term newborns, ${ }^{15}$ with a significant increase in births born at 37 and 38 weeks, and a decrease in those born at $\geq 39$ weeks, as have been described for other higher-income countries. ${ }^{29}$ This consideration might also explain the striking fact that birthweight is decreasing among newborns to Spanish mothers while the prevalence of preterm birth is decreasing. ${ }^{3}$

Limitations of our study include that the analysis carried out was necessarily restricted to those maternal-foetal variables available in the Spanish birth certificate, and data concerning some possible relevant confounding factors in the evaluation of birth outcome-namely 
anthropometry and health conditions of the mother, healthy behaviours, and weight gain during pregnancy — were not available. We have published a complementary analysis of the Spanish population using a data set based on hospital records that addresses some of these limitations. ${ }^{15}$ Strength of our study is that it is based on a large nationwide data set including all births in Spain from 2007 to 2015. Large-scale population-based data allows evaluating national temporal trends in maternal profile and in obstetric practice that could be having offsetting effects on birth outcome, both prior and during the current economic crisis.

\section{Conclusion}

Current demographic and reproductive trends affecting maternal profile and age at childbearing seem to be depth in Spain as in other higher-income countries, reinforced during the current economic crisis. Public health policies should focus on re-assessing the characterization of mature primipara mothers as a risk group with the goals of identifying their specific needs and concerns, ${ }^{30}$ and reversing the trend of increasing obstetric intervention over them, especially their extremely high rates of CS deliveries. As Panagopoulous et al. (2006) suggested, ${ }^{1}$ advanced maternal age should be considered as a risk indicator rather than a risk factor.

\section{References}

1. Panagopoulos P, Economou A, Tagia M, Siropoulos N, Doulia-Anagnostaki P, Katsetos C. Pregnancy outcome in nulliparous women at age $>35$ in comparison to younger nulliparous women. Giorn It Ost Gin 2006; 28(10/11):479-82.

2. Astolfi P, Zonta LA. Delayed maternity and risk at delivery. Paediatr Perinat Epidemiol 2002; 16(1):67-72.

3. OECD. Health at a Glance 2015: OECD Indicators. Paris, France: OECD Publishing, 2015. Available from: http://dx.doi.org/10.1787/health_glance-2015-en. 
4. Naeye RL. Maternal age, obstetric complications, and the outcome of pregnancy. Obstet Gynecol 1983; 61(2):210-6.

5. Prefumo F, Bhide A, Sairam S, Penna L, Hollis B, Thilaganathan B. Effect of parity on second-trimester uterine artery Doppler flow velocity and waveforms. Ultrasound Obstet Gynecol 2004; 23(1):46-9. http://dx.doi.org/10.1002/uog.908

6. Nelson SM, Telfer EE, Anderson RA. The ageing ovary and uterus: new biological insights. Hum Reprod Update 2013; 19(1):67-83. https://doi.org/10.1093/humupd/dms043

7. Smith GC, Cordeaux Y, White IR, Pasupathy D, Missfelder-Lobos H, Pell JP, et al. The effect of delaying childbirth on primary cesarean section rates. PLoS Med 2008; 5(7):e144. https://doi.org/10.1371/journal.pmed.0050144

8. Carolan M. Maternal age $\geq 45$ years and maternal and perinatal outcomes: A review of the evidence. Midwifery 2013; 29(5):479-89. https://doi.org/10.1016/j.midw.2012.04.001

9. Carolan M, Frankowska D. Advanced maternal age and adverse perinatal outcome: a review of the evidence. Midwifery 2011; 27(6):793-801. https://doi.org/10.1016/j.midw.2010.07.006

10. Kenny LC, Lavender T, McNamee R, O’Neill SM, Mills T, Khashan AS. Advanced maternal age and adverse pregnancy outcome: evidence from a large contemporary cohort. PLoS One 2013; 8(2):e56583. https://doi.org/10.1371/journal.pone.0056583

11. Oakley L, Penn N, Pipi M, Oteng-Ntim E, Doyle P. Risk of adverse obstetric and neonatal outcomes by maternal age: quantifying individual and population level risk using routine UK $\begin{array}{llll}\text { maternity data } & \text { One } & \text { 11(10):e0164462. }\end{array}$ https://doi.org/10.1371/journal.pone.0164462

12. European Commission. Demography Report. Luxembourg: Publications Office of the European Union, 2015. https://doi.org/10.2767/769227 
13. Varea C, Terán JM, Bernis C, Bogin B, González-González A. Is the economic crisis affecting birth outcome in Spain? Evaluation of temporal trend in underweight at birth (2003-2012). Ann Hum Biol 2016; 43(2):169-82. http://dx.doi.org/10.3109/03014460.2015.1131847

14. Juárez S, Alonso Ortíz T, Ramiro-Fariñas D, Bolúmar F. The quality of vital statistics for studying perinatal health: the Spanish case. Paediatr Perinat Epidemiol 2012; 26(4):310-5. http://dx.doi.org/10.1111/j.1365-3016.2012.01287.x

15. Bernis C, Varea C, Bogin B, González-González A. Labor management and mode of delivery among migrant and Spanish women: does the variability reflect differences in obstetric decisions according to ethnic origin? Matern Child Health J 2013; 17(5):918-27. https://doi.org/10.1007/s10995-012-1079-7

16. Cabañas F, López-Azorín M, Pellicer A. Impacto de las técnicas de reproducción asistida en la salud del recién nacido. An Pediatr (Barc) 2009; 70(4):319-22. https://doi.org/10.1016/j.anpedi.2009.02.001

17. Terán JM, Varea C, Bernis C, Bogin B, González-González A. New birthweight charts according to parity and type of delivery for the Spanish population. Gac Sanit 2017; 31(2):116-22. https://doi.org/10.1016/j.gaceta.2016.09.016

18. Rothman KJ, Greenland S, Lash TL. Validity in Epidemiologic studies. In: Rothman KJ, Greenland S, Lash TL, eds. Modern epidemiology, 3rd edn. Philadelphia, USA: Lippincott Williams \& Wilkins, 2008: 128-47.

19. Astolfi P, Ulizzi L, Zonta LA. Selective cost of delayed childbearing. Hum Reprod 1999; 14(2):572-3. https://doi.org/10.1093/humrep/14.2.572B

20. Cleary-Goldman J, Malone FD, Vidaver J, Ball RH, Nyberg DA, Comstock CH, et al. Impact of maternal age on obstetric outcome. Obstet Gynecol 2005; 105(5 Pt 1):983-90. 
21. Kozuki N, Lee AC, Silveira MF, Sania A, Vogel JP, Adair L, et al. The associations of parity and maternal age with small-for-gestational-age, preterm, and neonatal and infant mortality: a meta-analysis. BMC Public Health 2013; 13(Suppl 3):S2. https://doi.org/10.1186/1471-2458-13-S3-S2

22. Weng YH, Yang CY, Chiu YW. Risk Assessment of Adverse Birth Outcomes in Relation to Maternal Age. PLoS One 2014; 9(12):e114843. https://doi.org/10.1371/journal.pone.0114843

23. Johnson CD, Jones S, Paranjothy S. Reducing low birth weight: prioritizing action to address modifiable risk factors. $J$ Public Health 2017; 39(1):121-31. https://doi.org/10.1093/pubmed/fdv212

24. Bada HS, Das A, Bauer CR, Shankaran S, Lester BM, Gard CC, et al. Low birth weight and preterm births: etiologic fraction attributable to prenatal drug exposure. J Perinatol 2005; 25(10):631-7. https://doi.org/10.1038/sj.jp.7211378

25. Seo JH, Leem JH, Ha EH, Kim OJ, Kim BM, Lee JY, et al. Population-attributable risk of low birthweight related to PM10 pollution in seven Korean cities. Paediatr Perinat Epidemiol 2010; 24(2):140-8. https://doi.org/10.1111/j.1365-3016.2009.01085.X

26. Dunkel Schetter C, Niles AN, Guardino CM, Khaled M, Kramer MS. Demographic, medical, and psychosocial predictors of pregnancy anxiety. Paediatr Perinat Epidemiol 2016; 30(5):421-9. https://doi.org/10.1111/ppe.12300

27. Voight M, Heineck G, Hesse V. The relationship between maternal characteristics, birth weight and pre-term delivery: evidence from Germany at the end of the 20th century. Econ Hum Biol 2004; 2(2):265-80. https://doi.org/10.1016/j.ehb.2004.04.005

28. Peipert JF, Bracken MB. Maternal age: an independent risk factor for cesarean delivery. Obstet Gynecol 1993; 81(2):200-5. 
29. Davidoff MJ, Dias T, Damus K, Russell R, Bettegowda VR, Dolan S, et al. Changes in the gestational age distribution among U.S. singleton births: impact on rates of late preterm birth, 1992 to 2002. Semin Perinatol 2006; 30(1):8-15. https://doi.org/10.1053/j.semperi.2006.01.009

30. Carolan M. The project: Having a baby over 35 years. Women Birth 2007; 20(3):121-6. https://doi.org/10.1016/j.wombi.2007.05.004

\section{Acknowledgements}

There has not been financial assistance. 
Initial sample

$\mathrm{N}=4,118,803$

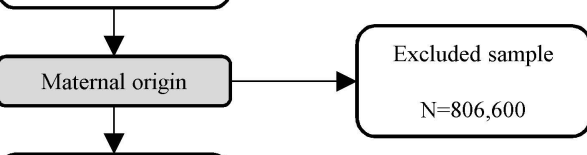

Spanish mothers

$\mathrm{N}=3,312,203$

Excluded sample

Single/multiple birth

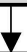

$\mathrm{N}=75,918$

Single births

$\mathrm{N}=3,236,285$

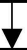

Live/death birth

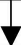

Excluded sample

$$
\mathrm{N}=8,742
$$

Live births

$\mathrm{N}=3,227,543$

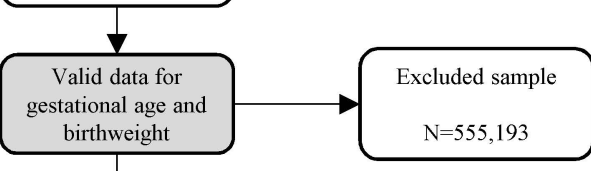

Final sample

$\mathrm{N}=2,672,350$ 


\section{a)}

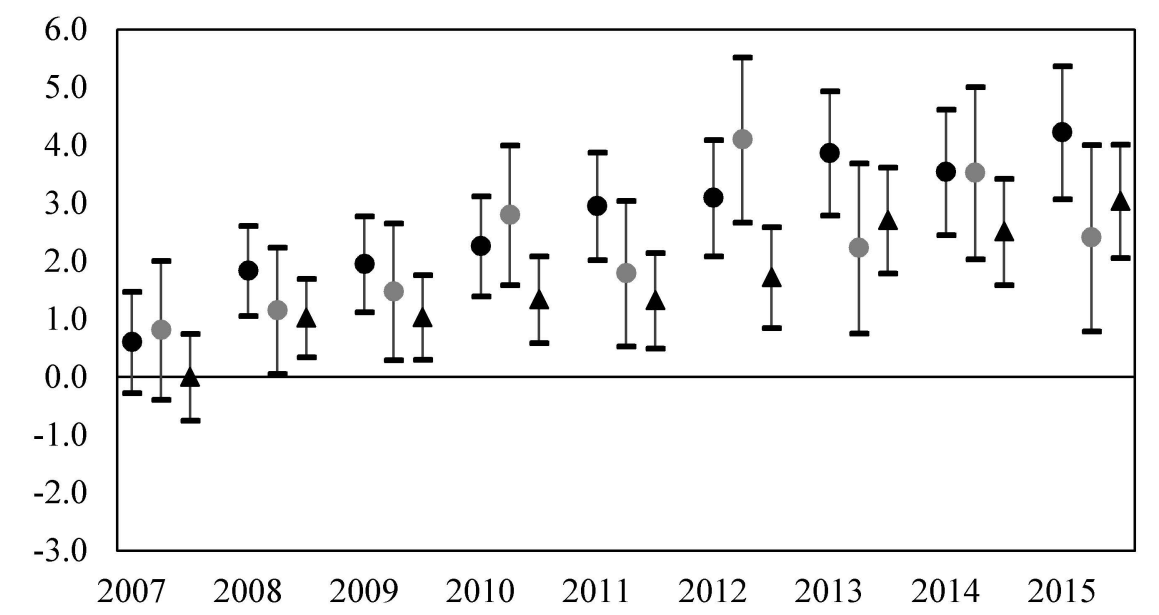

c)

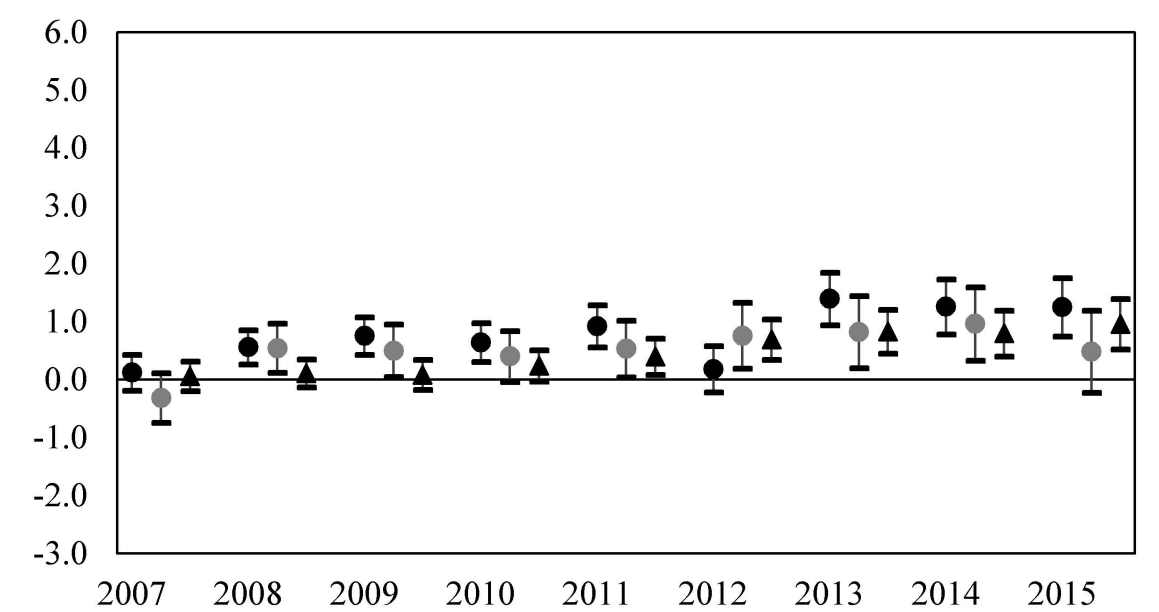

b)

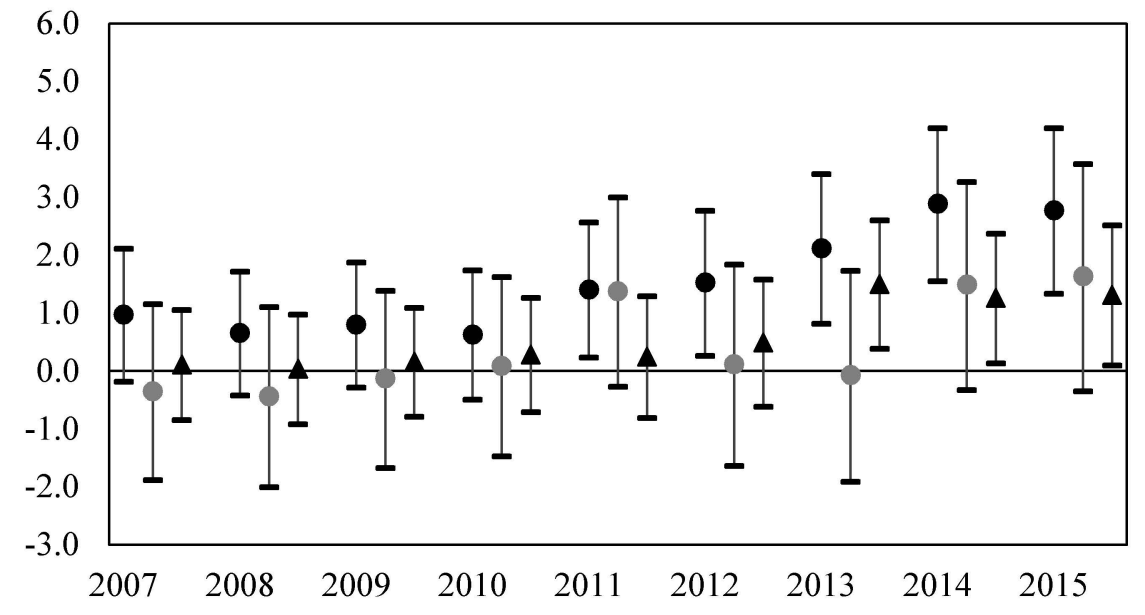

d)

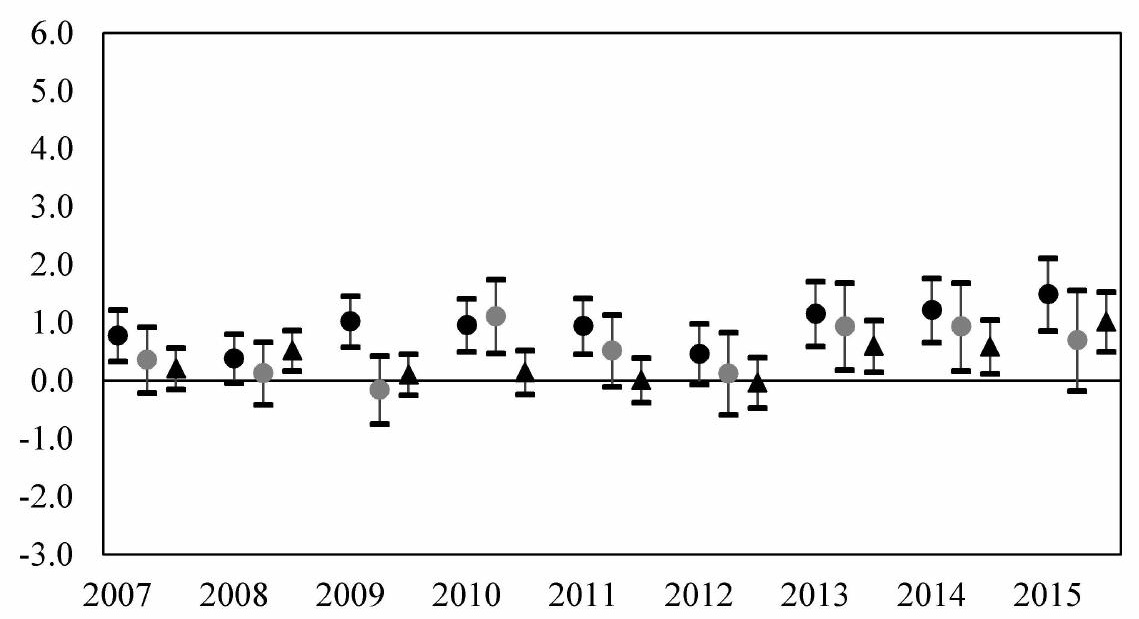


Table S1. Distribution and adjusted relative risk of SGA $<3^{\text {rd }}$, SGA $3^{\text {rd }}-5^{\text {th }}$, and SGA $5^{\text {th }}-10^{\text {th }}$ by age and parity (live single births, Spanish mothers, 2007-2015, data from Spanish Birth Statistical Bulletin).

\begin{tabular}{|c|c|c|c|c|c|c|}
\hline & \multicolumn{2}{|c|}{ SGA $<3^{\text {rd }}$} & \multicolumn{2}{|c|}{ SGA $3^{\text {rd }}-5^{\text {th }}$} & \multicolumn{2}{|c|}{ SGA $5^{\text {th }}-10^{\text {th }}$} \\
\hline & n (\%) & $\mathrm{RR}^{\mathrm{a}}(95 \% \mathrm{CI})$ & n (\%) & $\mathrm{RR}^{\mathrm{a}}(95 \% \mathrm{CI})$ & n (\%) & $\mathrm{RR}^{\mathrm{a}}(95 \% \mathrm{CI})$ \\
\hline \multicolumn{7}{|l|}{ Age at maternity } \\
\hline 30-34 years old (reference) & $33,284(36.5)$ & 1.00 & $18,402(37.5)$ & 1.00 & $47,545(37.8)$ & 1.00 \\
\hline$<20$ years old & $2,618(2.9)$ & $0.83(0.79,0.87)$ & $1,316(2.7)$ & $0.84(0.78,0.90)$ & $3,321(2.6)$ & $0.94(0.90,0.98)$ \\
\hline 20-24 years old & $5,335(5.8)$ & $0.90(0.87,0.93)$ & $2,781(5.7)$ & $0.89(0.85,0.94)$ & $6,628(5.3)$ & $0.92(0.89,0.94)$ \\
\hline 25-29 years old & $15,322(16.8)$ & $0.94(0.92,0.97)$ & $8,248(16.8)$ & $0.94(0.91,0.97)$ & $20,826(16.6)$ & $0.95(0.94,0.97)$ \\
\hline 35-39 years old & $27,520(30.1)$ & $1.10(1.08,1.12)$ & 14,701 (29.9) & $1.06(1.04,1.09)$ & $38,081(30.3)$ & $1.05(1.04,1.07)$ \\
\hline$\geq 40$ years old & $7,200(7.9)$ & $1.21(1.18,1.24)$ & $3,682(7.5)$ & $1.12(1.08,1.17)$ & $9,264(7.4)$ & $1.09(1.06,1.12)$ \\
\hline \multicolumn{7}{|l|}{ Parity } \\
\hline Multipara (reference) & $40,568(44.4)$ & 1.00 & 21,451 (43.7) & 1.00 & $55,487(44.2)$ & 1.00 \\
\hline Primipara & $50,711(55.6)$ & $1.08(1.06,1.09)$ & $27,679(56.3)$ & $1.08(1.06,1.11)$ & $70,178(55.8)$ & $1.05(1.03,1.06)$ \\
\hline \multicolumn{7}{|l|}{ Age at maternity and parity } \\
\hline 30-34 years old multipara (reference) & $13,378(14.7)$ & 1.00 & 7,330 (14.9) & 1.00 & $19,126(15.2)$ & 1.00 \\
\hline$<20$ years old primipara & $2,258(2.5)$ & $0.89(0.84,0.94)$ & $1,124(2.3)$ & $0.88(0.82,0.96)$ & $2,882(2.3)$ & $0.98(0.94,1.03)$ \\
\hline 20-24 years old primipara & $3,655(4.0)$ & $0.94(0.90,0.98)$ & $1,973(4.0)$ & $0.94(0.88,0.99)$ & $4,660(3.7)$ & $0.93(0.89,0.96)$ \\
\hline 25-29 years old primipara & $10,166(11.1)$ & $0.99(0.96,1.02)$ & $5,587(11.4)$ & $0.98(0.95,1.02)$ & $14,225(11.3)$ & $0.97(0.89,0.99)$ \\
\hline 30-34 years old primipara & $19,906(21.8)$ & $1.10(1.07,1.13)$ & $11,072(22.5)$ & $1.07(0.95,1.02)$ & $28,419(22.6)$ & $1.05(1.03,1.07)$ \\
\hline 35-39 years old primipara & $11,938(13.1)$ & $1.24(1.21,1.28)$ & $6,469(13.2)$ & $1.20(1.16,1.24)$ & $16,304(13.0)$ & $1.14(1.11,1.16)$ \\
\hline$\geq 40$ years old primipara & $2,788(3.1)$ & $1.32(1.26,1.38)$ & $1,454(3.0)$ & $1.21(1.13,1.28)$ & $3,688(2.9)$ & $1.17(1.13,1.22)$ \\
\hline$<20$ years old multipara & $360(0.4)$ & $1.03(0.92,1.17)$ & $192(0.4)$ & $1.02(0.86,1.22)$ & $439(0.3)$ & $1.03(0.92,1.15)$ \\
\hline 20-24 years old multipara & $1,680(1.8)$ & $1.05(0.99,1.11)$ & $808(1.6)$ & $0.97(0.89,1.05)$ & $1,968(1.6)$ & $1.02(0.97,1.08)$ \\
\hline 25-29 years old multipara & $5,156(5.6)$ & $1.05(1.01,1.08)$ & $2,661(5.4)$ & $1.02(0.97,1.07)$ & $6,601(5.3)$ & $1.03(0.99,1.06)$ \\
\hline 35-39 years old multipara & $15,582(17.1)$ & $1.09(1.06,1.11)$ & $8,232(16.8)$ & $1.02(0.99,1.06)$ & 21,777 (17.3) & $1.03(1.01,1.05)$ \\
\hline$\geq 40$ years old multipara & $4,412(4.8)$ & $1.22(1.18,1.27)$ & $2,228(4.5)$ & $1.12(1.07,1.18)$ & $5,576(4.4)$ & $1.08(1.04,1.11)$ \\
\hline
\end{tabular}

${ }^{a}$ Adjusted by maternal occupation, maternal education, marital status, gestational age, type of birth, parity and the interaction term between age at maternity and parity 
Table S2. Adjusted population attributable fraction for SGA $<3^{\text {rd }}$, SGA $3^{\text {rd }}-5^{\text {th }}$, and SGA $5^{\text {th }}-10^{\text {th }}$ by age at maternity and parity (live single births, Spanish mothers, 2007-2015, data from Spanish Birth Statistical Bulletin).

\begin{tabular}{|c|c|c|c|c|c|c|}
\hline \multirow{3}{*}{ Age at maternity 35-39 years old } & \multicolumn{3}{|c|}{ Primipara } & \multicolumn{3}{|c|}{ Multipara } \\
\hline & SGA $<3^{\text {rd }}$ & SGA $3^{\text {rd }}-5^{\text {th }}$ & SGA $5^{\text {th }}-10^{\text {th }}$ & SGA $<3^{\text {rd }}$ & $\mathrm{SGA} 3^{\text {rd }}-5^{\text {th }}$ & SGA $5^{\text {th }}-10^{\text {th }}$ \\
\hline & $\operatorname{PAF}^{\mathrm{a}}(95 \% \mathrm{CI})$ & $\operatorname{PAF}^{\mathrm{a}}(95 \% \mathrm{CI})$ & $\operatorname{PAF}^{\mathrm{a}}(95 \% \mathrm{CI})$ & $\operatorname{PAF}^{\mathrm{a}}(95 \% \mathrm{CI})$ & $\operatorname{PAF}^{\mathrm{a}}(95 \% \mathrm{CI})$ & $\operatorname{PAF}^{\mathrm{a}}(95 \% \mathrm{CI})$ \\
\hline 2007 & $0.61(-0.27,1.48)$ & $0.89(-0.39,2.01)$ & $0.00(-0.75,0.75)$ & $0.97(-0.18,2.11)$ & $-0.35(-1.88,1.16)$ & $0.11(-0.84,1.06)$ \\
\hline 2008 & $1.84(1.06,2.61)$ & $1.15(0.06,2.24)$ & $1.02(0.35,1.70)$ & $0.66(-0.42,1.72)$ & $-0.43(-2.00,1.11)$ & $0.04(-0.91,0.98)$ \\
\hline 2009 & $1.96(1.13,2.78)$ & $1.48(0.29,2.66)$ & $1.04(0.30,1.76)$ & $0.80(-0.28,1.88)$ & $-0.13(-1.67,1.39)$ & $0.16(-0.78,1.10)$ \\
\hline 2010 & $2.27(1.40,3.13)$ & $2.80(1.59,4.00)$ & $1.34(0.59,2.09)$ & $0.63(-0.49,1.74)$ & $0.09(-1.47,1.63)$ & $0.29(-0.70,1.27)$ \\
\hline 2011 & $2.96(2.02,3.88)$ & $1.79(0.53,3.04)$ & $1.33(0.50,2.15)$ & $1.41(0.24,2.57)$ & $1.38(-0.27,3.00)$ & $0.25(-0.80,1.30)$ \\
\hline 2012 & $3.10(2.09,4.09)$ & $4.10(2.67,5.52)$ & $1.73(0.85,2.59)$ & $1.53(0.27,2.77)$ & $0.12(-1.64,1.84)$ & $0.49(-0.61,1.58)$ \\
\hline 2013 & $3.87(2.80,4.94)$ & $2.23(0.75,3.69)$ & $2.71(1.79,3.62)$ & $2.12(0.82,3.41)$ & $-0.07(-1.91,1.74)$ & $1.50(0.39,2.61)$ \\
\hline 2014 & $3.54(2.45,4.62)$ & $3.53(2.04,5.01)$ & $2.51(1.59,3.43)$ & $2.89(1.56,4.20)$ & $1.49(-0.32,3.27)$ & $1.26(0.14,2.38)$ \\
\hline 2015 & $4.23(3.08,5.37)$ & $2.41(0.79,4.01)$ & $3.04(2.06,4.02)$ & $2.78(1.34,4.20)$ & $1.64(-0.35,3.58)$ & $1.32(0.10,2.52)$ \\
\hline \multirow{3}{*}{ Age at maternity $\geq 40$ years old } & & Primipara & & \multicolumn{3}{|c|}{ Multipara } \\
\hline & $\mathrm{SGA}<3^{\text {rd }}$ & SGA $3^{\text {rd }}-5^{\text {th }}$ & SGA $5^{\text {th }}-10^{\text {th }}$ & $\mathrm{SGA}<3^{\text {rd }}$ & SGA $3^{\text {rd }}-5^{\text {th }}$ & SGA $5^{\text {th }}-10^{\text {th }}$ \\
\hline & $\operatorname{PAF}^{\mathrm{a}}(95 \% \mathrm{CI})$ & $\operatorname{PAF}^{\mathrm{a}}(95 \% \mathrm{CI})$ & $\operatorname{PAF}^{\mathrm{a}}(95 \% \mathrm{CI})$ & $\operatorname{PAF}^{\mathrm{a}}(95 \% \mathrm{CI})$ & $\operatorname{PAF}^{\mathrm{a}}(95 \% \mathrm{CI})$ & $\operatorname{PAF}^{\mathrm{a}}(95 \% \mathrm{CI})$ \\
\hline 2007 & $0.13(-0.18,0.43)$ & $-031(-0.74,0.11)$ & $0.06(-0.19,0.32)$ & $0.79(0.34,1.23)$ & $0.36(-0.21,0.93)$ & $0.22(-0.14,0.57)$ \\
\hline 2008 & $0.57(0.27,0.86)$ & $0.55(0.12,0.97)$ & $0.12(-0.13,0.36)$ & $0.39(-0.03,0.81)$ & $0.13(-0.41,0.67)$ & $0.53(0.18,0.87)$ \\
\hline 2009 & $0.76(0.44,1.09)$ & $0.51(0.05,0.96)$ & $0.09(-0.17,0.35)$ & $1.03(0.58,1.46)$ & $-0.15(-0.74,0.43)$ & $0.11(-0.25,0.46)$ \\
\hline 2010 & $0.65(0.31,0.98)$ & $0.41(-0.03,0.84)$ & $0.24(-0.03,0.51)$ & $0.97(0.51,1.42)$ & $1.12(0.48,1.75)$ & $0.15(-0.23,0.53)$ \\
\hline 2011 & $0.93(0.56,1.29)$ & $0.54(0.05,1.03)$ & $0.40(0.09,0.72)$ & $0.95(0.46,1.43$ & $0.53(-0.10,1.14)$ & $0.02(-0.37,0.40)$ \\
\hline 2012 & $0.19(-0.21,0.58)$ & $0.76(0.19,1.33)$ & $0.70(0.35,1.04)$ & $0.47(-0.06,0.99)$ & $0.13(-0.58,0.84)$ & $-0.03(-0.47,0.41)$ \\
\hline 2013 & $1.40(0.95,1.85)$ & $0.83(0.20,1.45)$ & $0.84(0.46,1.21)$ & $1.16(0.60,1.71)$ & $0.94(0.19,1.69)$ & $0.60(0.15,1.05)$ \\
\hline 2014 & $1.27(0.79,1.74)$ & $0.97(0.33,1.60)$ & $0.80(0.40,1.20)$ & $1.22(0.66,1.77)$ & $0.94(0.18,1.69)$ & $0.59(0.12,1.06)$ \\
\hline 2015 & $1.26(0.75,1.76)$ & $0.49(-0.22,1.20)$ & $0.97(0.53,1.40)$ & $1.50(0.87,2.12)$ & $0.70(-0.17,1.56)$ & $1.02(0.50,1.54)$ \\
\hline
\end{tabular}

SGA, small for gestational age: PAF, population attributable fraction; $\mathrm{CI}$, confidence interval.

a Adjusted by maternal occupation, maternal education, marital status, gestational age, type of birth, parity and the interaction term between age at maternity and parity. 

Table 1. Temporal trends in maternal-foetal variables (live single births, Spanish mothers, selected years 2007, 2010, 2015, data from Spanish Birth Statistical Bulletin).

\begin{tabular}{|c|c|c|c|c|}
\hline & $\begin{array}{l}2007 \\
\text { n (\%) }\end{array}$ & $\begin{array}{l}2010 \\
\text { n (\%) }\end{array}$ & $\begin{array}{l}2015 \\
\text { n (\%) }\end{array}$ & $\begin{array}{c}\text { Chi-sq. test } \\
p \text {-value }\end{array}$ \\
\hline Distribution & $308,877(34.5)$ & 305,927 (34.2) & $279,234(31.2)$ & \\
\hline \multicolumn{5}{|l|}{ Age at maternity } \\
\hline$<20$ years old & $5,479(1.8)$ & $4,627(1.5)$ & $3,654(1.3)$ & \multirow{6}{*}{$<0.001$} \\
\hline 20-24 years old & 19,427 (6.3) & $17,871(5.8)$ & 14,239 (5.1) & \\
\hline 25-29 years old & 59,697 (19.3) & 49,742 (16.3) & $40,106(14.4)$ & \\
\hline 30-34 years old & $128,635(41.6)$ & $122,799(40.1)$ & $98,167(35.2)$ & \\
\hline 35-39 years old & 79,972 (25.9) & $91,442(29.9)$ & $95,788(34.3)$ & \\
\hline$\geq 40$ years old & $15,667(5.1)$ & $19,446(6.4)$ & $27,280(9.8)$ & \\
\hline \multicolumn{5}{|l|}{ Maternal occupation } \\
\hline Professionals & $68,476(25.6)$ & $89,020(29.8)$ & $85,786(34.0)$ & \multirow{8}{*}{$<0.001$} \\
\hline Administrative employees & 64,245 (24.1) & $72,346(24.2)$ & $52,835(20.9)$ & \\
\hline Service sector workers & 48,291 (18.1) & $54,077(18.1)$ & 49,890 (19.8) & \\
\hline Primary sector workers & $3,092(1.2)$ & $3,075(1.0)$ & $2,602(1.0)$ & \\
\hline Qualified workers & $8,968(3.4)$ & $9,021(3.0)$ & $6,292(2.5)$ & \\
\hline Unskilled workers & $13,589(5.1)$ & $16,440(5.5)$ & $12,303(4.9)$ & \\
\hline Students & $2,808(1.1)$ & $3,702(1.2)$ & $4,163(1.6)$ & \\
\hline Housewives & $57,589(21.6)$ & $51,283(17.2)$ & 38,627 (15.3) & \\
\hline \multicolumn{5}{|l|}{ Maternal education } \\
\hline University education & $100,035(34.2)$ & $117,296(39.1)$ & $104,500(41.4)$ & \multirow{3}{*}{$<0.001$} \\
\hline Secondary education & $165,088(56.4)$ & $155,830(51.9)$ & $124,080(49.2)$ & \\
\hline Primary education & $27,398(9.4)$ & $27,039(9.0)$ & 23,625 (9.4) & \\
\hline \multicolumn{5}{|l|}{ Marital status } \\
\hline Married & $221,512(75.7)$ & $199,433(69.9)$ & $150,350(61.6)$ & \multirow{3}{*}{$<0.001$} \\
\hline Unmarried with a stable partner & $48,881(16.7)$ & $51,027(17.9)$ & $49,915(20.5)$ & \\
\hline Unmarried with non-stable partner & $22,389(7.6)$ & $35,052(12.3)$ & 43,637 (17.9) & \\
\hline \multicolumn{5}{|l|}{ Residence } \\
\hline Rural & $250,849(18.8)$ & $249,497(18.4)$ & $50,043(17.9)$ & $<0.001$ \\
\hline \multicolumn{5}{|l|}{ Sex of newborn } \\
\hline Male & $159,577(51.7)$ & $157,736(51.6)$ & $143,732(51.5)$ & n.s. \\
\hline \multicolumn{5}{|l|}{ Parity } \\
\hline Primipara & $182,521(59.1)$ & $167,587(54.8)$ & $149,634(53.6)$ & $<0.001$ \\
\hline \multicolumn{5}{|l|}{ Type of birth } \\
\hline CS delivery & $74,182(25.4)$ & $78,909(25.8)$ & 70,132 (25.1) & $<0.001$ \\
\hline \multicolumn{5}{|l|}{ Gestational age } \\
\hline Preterm birth & $18,726(6.1)$ & $17,670(5.8)$ & $15,209(5.4)$ & $<0.001$ \\
\hline \multicolumn{5}{|l|}{ Weight for gestational age } \\
\hline $\operatorname{SGA}\left(<10^{\text {th }}\right)$ & $28,751(9,8)$ & $31,162(10.3)$ & $27,863(10,0)$ & $<0.001$ \\
\hline SGA $\left(<3^{\text {rd }}\right)$ & $9,647(3.3)$ & $10,899(3.6)$ & $9,162(3.3)$ & $<0.001$ \\
\hline $\operatorname{SGA}\left(3^{\text {rd }}-5^{\text {th }}\right)$ & $5,452(1.9)$ & $5,712(1.9)$ & $5,231(1.9)$ & n.s. \\
\hline SGA $\left(5^{\text {th }}-10^{\text {th }}\right)$ & $13,652(4.7)$ & $14,551(4.8)$ & $13,470(4.8)$ & $<0.050$ \\
\hline
\end{tabular}

Chi-sq. test, chi-square test; CS delivery, caesarean section delivery; LBW, low birthweight; SGA, small for gestational age; n.s., not significant. 
Table 2. Maternal and foetal characteristics by age at maternity (live single births, Spanish mothers, 2007-2015, data from Spanish Birth Statistical Bulletin).

\begin{tabular}{|c|c|c|c|c|c|c|c|}
\hline & $\begin{array}{c}<20 \text { years old } \\
\mathrm{n}(\%)\end{array}$ & $\begin{array}{l}\text { 20-24 years old } \\
\text { n (\%) }\end{array}$ & $\begin{array}{l}\text { 25-29 years old } \\
\text { n (\%) }\end{array}$ & $\begin{array}{c}\text { 30-34 years old } \\
\mathrm{n}(\%)\end{array}$ & $\begin{array}{l}\text { 35-39 years old } \\
\text { n (\%) }\end{array}$ & $\begin{array}{l}\geq 40 \text { years old } \\
n(\%)\end{array}$ & $\begin{array}{c}\text { Chi-sq. test } \\
p \text {-value }\end{array}$ \\
\hline Distribution & $39,958(1.5)$ & $151,274(5.7)$ & $432,254(16.2)$ & $1,040,304$ (38.9) & $818,125(30.6)$ & $190,435(7.1)$ & \\
\hline \multicolumn{8}{|l|}{ Maternal occupation } \\
\hline Professionals & $1,245(3.4)$ & $8,203(5.8)$ & 72,745 (17.9) & 327,391 (32.9) & $296,623(37.7)$ & $69,146(37.8)$ & \multirow{8}{*}{$<0.001$} \\
\hline Administrative employees & $1,199(3.3)$ & $10,457(7.4)$ & 74,995 (18.4) & $250,198(25.2)$ & $210,172(26.7)$ & $46,118(25.2)$ & \\
\hline Service sector workers & $2,624(7.1)$ & $31,741(22.6)$ & $109,296(26.8)$ & $184,338(18.5)$ & $116,093(14.8)$ & $24,864(13.6)$ & \\
\hline Primary sector workers & $326(0.9)$ & $2,451(1.7)$ & $6,165(1.5)$ & $9,733(1.0)$ & $6,426(0.8)$ & $1,555(0.9)$ & \\
\hline Qualified workers & $331(0.9)$ & $3,120(2.2)$ & $14,885(3.7)$ & $33,122(3.3)$ & $22,760(2.9)$ & $4,847(2.7)$ & \\
\hline Unskilled workers & $2,279(6.2)$ & $12,524(8.9)$ & $29,198(7.2)$ & $47,073(4.7)$ & $32,895(4.2)$ & $8,544(4.7)$ & \\
\hline Students & $9,424(25.6)$ & $10,787(7.7)$ & 6,889 (1.7) & $6,084(0.6)$ & $109(0.0)$ & $14(0.0)$ & \\
\hline Housewives & $19,410(52.7)$ & $61,156(43.5)$ & $93,004(22.8)$ & $135,881(13.7)$ & $101,181(12.9)$ & 27,669 (15.9) & \\
\hline \multicolumn{8}{|l|}{ Maternal education } \\
\hline University education & $205(0.6)$ & $3,575(2.5)$ & 77,617 (18.7) & $430,002(42.9)$ & $403,782(51.5)$ & 89,205 (49.6) & \multirow{3}{*}{$<0.001$} \\
\hline Secondary education & $10,975(30.4)$ & $76,256(53.8)$ & $277,359(66.9)$ & $526,776(52.5)$ & $352,141(44.9)$ & $81,406(45.2)$ & \\
\hline Primary education & $24,884(69.0)$ & $61,980(43.7)$ & $59,906(14.4)$ & $45,698(4.6)$ & $28,561(3.6)$ & $9,414(5.2)$ & \\
\hline \multicolumn{8}{|l|}{ Marital status } \\
\hline Married & $1,867(5.7)$ & $26,131(20.6)$ & $225,933(58.3)$ & $731,606(75.3)$ & $579,078(75.7)$ & $120,153(68.6)$ & \multirow[b]{2}{*}{$<0.001$} \\
\hline Unmarried with a stable partner & $15,496(47.3)$ & $54,553(43.1)$ & $94,236(24.3)$ & $143,988(14.8)$ & $113,230(14.8)$ & $33,296(19.0)$ & \\
\hline \multicolumn{8}{|l|}{ Residence } \\
\hline Rural & $5,607(14.0)$ & $25,853(17.1)$ & $90,129(20.9)$ & $199,844(19.2)$ & $136,656(16.7)$ & 29,380 (15.4) & $<0.001$ \\
\hline \multicolumn{8}{|l|}{ Sex of newborn } \\
\hline Male & $20,762(52.0)$ & $78,356(51.8)$ & $223,216(51.6)$ & $537,515(51.7)$ & $421,472(51.5)$ & $97,236(51.1)$ & $<0.001$ \\
\hline \multicolumn{8}{|l|}{ Parity } \\
\hline Primipara & $36,311(90.9)$ & $112,232(74.2)$ & $304,822(70.5)$ & $618,698(59.5)$ & $333,201(40.7)$ & 72,197 (37.9) & $<0.001$ \\
\hline \multicolumn{8}{|l|}{ Type of birth } \\
\hline CS delivery & $5,607(14.1)$ & $25,735(17.1)$ & $89,203(20.8)$ & $235,045(22.7)$ & $209,852(25.8)$ & $64,089(33.8)$ & $<0.001$ \\
\hline \multicolumn{8}{|l|}{ Gestational age } \\
\hline Preterm birth & 3,653 (9.1) & $10,138(6.7)$ & $24,023(5.6)$ & $54,200(5.2)$ & $46,755(5.7)$ & $13,586(7.1)$ & $<0.001$ \\
\hline \multicolumn{8}{|l|}{ Weight for gestational age } \\
\hline SGA $\left(<10^{\text {th }}\right)$ & 4,617 (11.7) & $17,382(11.6)$ & $44,396(10.4)$ & $99,231(9.6)$ & 80,302 (9.9) & $20,146(10.6)$ & $<0.001$ \\
\hline SGA $\left(<3^{\text {rd }}\right)$ & $1,689(4.3)$ & $6,264(4.2)$ & $15,322(3.6)$ & $33,284(3.2)$ & $27,520(3.4)$ & $7,200(3.8)$ & $<0.001$ \\
\hline $\operatorname{SGA}\left(3^{\text {rd }}-5^{\text {th }}\right)$ & $820(2.1)$ & $3,277(2.2)$ & $8,248(1.9)$ & $18,402(1.8)$ & $14,701(1.8)$ & $3,682(1.9)$ & $<0.001$ \\
\hline SGA $\left(5^{\text {th }}-10^{\text {th }}\right)$ & $2,108(5.3)$ & $7,841(5.2)$ & $20,826(4.9)$ & $47,545(4.6)$ & $38,081(4.7)$ & $9,264(4.9)$ & $<0.001$ \\
\hline
\end{tabular}

Chi-sq. test, chi-square test; CS delivery, caesarean section delivery; LBW, low birthweight; SGA, small for gestational age. 
